\title{
legelivet
}

På disse sidene i Tidsskriftet - legelivet - finner du stoff om legers liv.

Her er det presentasjon av arbeidssteder, nyhetssaker, nye doktorgrader,

nye spesialister og minneord. Alt samlet på ett sted - så du kan følge enda bedre med.

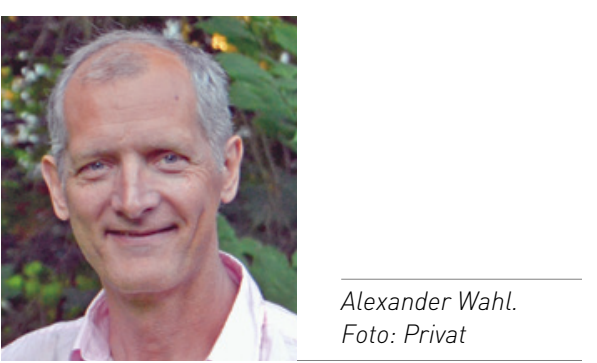

Alexander Wahl (f. 1963) er veileder i allmennmedisin og spesialist i allmennmedisin og arbeider ved Kurbadet Legesenter. Han er også redaktør for primærhelsetjenesten i Helsebiblioteket.

\section{Billett merket kontakt}

Da jeg vokste opp, ble følelsesregisteret mitt pepret med kjærlighetssanger fra The Beatles. Storebror var svoren tilhenger og bestemte vinylvalget på platespilleren. Jeg ble tidlig formet som en romantiker, med sanger som I want to hold your hand.

Dette romantiske sinnelaget fikk seg en støkk da jeg i 1980-årene kom over noen små unnselige annonser i Dagbladet. Det var kontaktannonser. På få linjer ble lengsel annonsert, og en liten kontrakt formulert: «Velsituert herre søker kvinnelig selskap, $100 \%$ diskresjon.» Et kjønnsmarked foldet seg ut. De korte linjene antydet en handelstankegang som var sjokkerende for meg. Det smakte av gjensidig utnyttelse, men kunne man fordømme det når begge søkte en avtale? Mellom linjene ante jeg flust med dramatikk - kanskje fattigdom - og i hvert fall ensomhet og fortvilet lengsel etter kjærlighet.

I dag har bill. mrk.-annonsene skiftet form. Lengslenes flammer slynges ut på Møteplassen og Tinder, og jeg tipper at mange forbrenner seg i et mye raskere tempo. Vi har neppe oversikt over hva det betyr for folkehelsen.

Det finnes over én million aleneboende i Norge. Mange av dem er unge som søker Love, love me do, og i allmennpraksis møter vi dem av og til. Men ensomhet er ofte tabu og skam. Den kan komme til uttrykk på mange måter, for eksempel «jeg har så lite energi, doktor». Og vi tar dem imot helt for- skjellig - avhengig av hvem vi er, og hva vi definerer som vårt arbeidsområde. Det letteste er selvfølgelig å ta noen blodprøver. Men blodprøvene er som regel normale, og blodtapping er en dårlig kur mot ensomhet. Om vi klarer å gå bak fasaden og finne nøkkelspørsmålet som åpner for samtalen, blir allmennpraksis spennende, ja, noen ganger gripende. Da får vi høre om det motet som kreves for å date. «Ingenting skjer hvis jeg bare sitter og ser på TV», sa en pasient til meg, vel vitende om farene der ute. «Jeg har ikke sommerfugler i magen når jeg går på date - inni meg flakser det havørn.» Slike formuleringer er fortrolighetens små gaver.

Som fortrolig samtalepartner kan fastlegen komme med innspill om grenser og sikkerhet og høre på deres Help, I need somebody. Samtalene gir mening, de er sentrale, og pasienten unngår henvisninger og unødvendig overutredning. Og da har vi lykkes med én god ting. Vi har opprettet kontakt - jaggu meg bill. mrk.-kontakt.

\section{Alexander Wahl}

alexanderwahl32@gmail.com 